
The publishers wish to express their gratitude to Joan Palevsky for her most generous contribution to the publication of this book. 
EPIGRAMS OF MARTIAL ENGLISHED BY DIVERS HANDS 



\section{EPIGRAMS OF MARTIAL}

ENGLISHED BY DIVERS HANDS

SELECTED AND EDITED

WITH AN INTRODUCTION BY

J. P. SULLIVAN AND

PETER WHIGHAM

UNIVERSITY OF CALIFORNIA PRESS BERKELEY • LOS ANGELES • LONDON 
The preparation of this volume was made possible by a grant from the Translations Program of the National Endowment for the Humanities, an independent federal agency.

University of Califomia Press
Berkeley and Los Angeles, California

University of California Press, Ltd.

London, England

- 1987 by The Regents of the University of California

\author{
Library of Congress Cataloging-in-Publication Data \\ Martial. \\ Epigrams of Martial Englished by divers hands. \\ Bibliography: $\mathbf{p}$. \\ Includes index. \\ 1. Martial-Translations, English. 2. Epigrams, \\ Latin-Translations into English. 3. Epigrams, \\ English-Translations from Latin. I. Sullivan, J. P. \\ (John Patrick). II. Whigham, Peter. III. Title. \\ PA6502.S85 $1987 \quad 878^{\prime} .0102 \quad 86-4301$ \\ ISBN 0.520-04240-9 (alk. paper) \\ ISBN 0-520-0424I-7 (pbk. : alk. paper)
}

Printed in the United States of America

$\begin{array}{lllllllll}1 & 2 & 3 & 4 & 5 & 6 & 7 & 8 & 9\end{array}$

I. V. Cunningham: Translations of II.S and IV.69 from Collected Poems and Epigrams of I.V. Cunningham, Swallow Press, 1971. Reprinted by permission of The Ohio University Press, Athens, Ohio.

Dudley Fitts: From his Sixty Poems of Martial in Translation: VIII. 69 ("To His Critics") ${ }^{\circ} 1961$ by Dudley Fitts; II. 53 ("To Chloe"), VI. 57 ("Every Man His Own Absalom"), and XI.85 ("On Zorlus, a Linguist"), ${ }^{1967}$ by Dudley Fitts. Reprinted by permission of Harcourt Brace Jovanovich, Inc.

Brian Hill: Translations reprinted by permission of the author's literary executor, Timothy d'Arch Smith.

Rolfe Humphries: Translations of 1.64 and IX.33 from Selected Epigrams of Martial, Indiana University Press, 1963 . Reprinted by permission of the publisher.

Ralph Marcellino: Translations of I.25 and VII 19 from Martial: Selected Epjgrams. ${ }^{\circ} 1968$ by Macmillan Publishing Company. Reprinted with permission of the publisher.

Philip Murray: Translations of I.103, IV.46, and XII $82{ }^{\circ} 1967$ by Philip Murray. Reprinted from Poems after Martial by permission of Wesleyan University press.

Peter Porter: From his After Mortial. Oxford University Press, 1972. Reprinted by permission of the publisher and the author

I. A. Pott and F.A. Wright: From Martial, the Twelve Books of Epigrams, Routledge and Kegan Paul, 1924. Reprinted by permission of the publisher.

Ezra Pound: Translation of V.43 from Personae, ${ }^{\circ} 1926$ by Ezra Pound. Reprinted by permission of New Directions Publishing Corporation.

Dorothea Wender: From Roman Poetry: From the Republic to the Silver Age. ${ }^{\circ}$ I980 by Southem Illinois University Press. Reprinted by permission of the publisher and the author. 
Omne epigramma sit instar apis; sit aculeus illi; Sint sua mella; sit et corporis exigui.

The qualities rare in a bee that we meet, In an epigram never should fail; The body should always be little and sweet And a sting should be left in its tail. Lord Chesterfield

Martial, in sooth none should presume to write, Since time hath brought thy Epigrams to light: For through our writing, thine so prais'd before Have this obtained, to be commended more:

Yet to ourselves although we win no fame, We please, which get our master a good name. Thomas Bastard, Chrestoleros I. I7

And then what proper person can be partial To all those nauseous epigrams of Martial? 
